\title{
The helminth community of the agile frog, Rana dalmatina Bonaparte, 1839 (Anura: Ranidae) collected from Northwest of Turkey
}

\author{
S. DÜŞEN ${ }^{1}$ İ. H. UĞURTAŞ², A. AYDOĞDU ${ }^{3}$, M. C. OĞUZ ${ }^{4}$
}

\author{
${ }^{1}$ Pamukkale University, Faculty of Arts and Sciences, Department of Biology, Kınıklı Campus, \\ 20017 Denizli-TURKEY, E-mail: sdusen@pamukkale.edu.tr, serdar2290@yahoo.com; ${ }^{2}$ Uludağ University, \\ Faculty of Arts and Sciences, Department of Biology, Görükle Campus, 16059 Bursa-TURKEY; ${ }^{3}$ Uludağ University, \\ Mustafakemalpaşa Vocational High School, Mustafakemalpaşa, Bursa-TURKEY; ${ }^{4}$ Atatürk University, \\ Faculty of Sciences, Department of Biology, 25240 Erzurum-TURKEY
}

\begin{abstract}
Summary
A total of 33 agile frogs (Rana dalmatina) were collected from 7 localities in Edirne, Bursa and Adapazarı Provinces (Northwest of Turkey), between 1987 - 2007 and examined for the first time for helminths. R. dalmatina harbored one species of Monogenea (Polystoma sp.), 3 species of Digenea (Diplodiscus subclavatus, Pleurogenoides medians, and Pleurogenes claviger), 4 species of Nematoda (Rhabdias bufonis, Oswaldocruzia filiformis, Cosmocerca ornata, and Oxysomatium brevicaudatum) and one species of Acanthocephala (Acanthocephalus ranae). All helminths represent new host records for Rana dalmatina in Turkey.
\end{abstract}

Keywords: helminth; agile frog; Rana dalmatina; Turkey

\section{Introduction}

The agile frog Rana dalmatina Bonaparte, 1839 is a medium sized strictly terrestrial, anuran species, that lives in deciduous forests, damp grasslands with higher vegetation, and usually quite far away from water bodies up to $1500 \mathrm{~m}$ elevation. $R$. dalmatina is found in Turkish Thrace and northern parts of Anatolia. The species is mainly nocturnal, its diet consists of various insects (Baran and Atatür, 1997).

Previous reports have identified various species of Digenea, Nematoda and Acanthocephala from $R$. dalmatina collected from Bulgaria and the former Czechoslovakia (Vojtkova \& Vojtek, 1975; Buchvarov et al. 1975; Buchvarov, 1977 and Kirin \& Buchvarov, 2002). Only one polystome species have been reported from $R$. dalmatina in Bulgaria (Buchvarov, 1980). A leech was also reported by Buchvarov (1977) in Bulgaria. Thus, a total of 21 species of helminths have been reported from $R$. dalmatina.

So far, there has been no published study on helminths of the agile frog $(R$. dalmatina) in Turkey. We report for the first time helminths of $R$. dalmatina from Turkey.

\section{Materials and Methods}

Frogs were collected by hand, between 1987-2007 from 7 localities in Turkey: Büyükdöllük (120 m) Edirne Province $\left(41^{0} 45^{\prime} \mathrm{N} ; 26^{0} 36^{\prime}\right.$ E), Uludağ Mountain (1200 m), Bursa Province $\left(40^{0} 09^{\prime} \mathrm{N} ; 29^{0} 05^{\prime} \mathrm{E}\right)$, Karacabey $(50 \mathrm{~m})$, Bursa province $\left(40^{\circ} 13^{\prime} \mathrm{N} ; 28^{\circ} 21^{\prime} \mathrm{E}\right)$, İnegöl $(450 \mathrm{~m})$ Bursa province $\left(40^{\circ} 04^{\prime} \mathrm{N}\right.$; $\left.23^{0} 30^{\prime} \mathrm{E}\right)$, Kemalpaşa $(160 \mathrm{~m})$ Bursa province $\left(40^{\circ} 02^{\prime} \mathrm{N} ; 28^{0} 24^{\prime}\right.$ E), Akyazı $(200 \mathrm{~m})$, Adapazarı Province $\left(40^{\circ} 41^{\prime} \mathrm{N} ; 30^{\circ} 41^{\prime} \mathrm{E}\right)$, Karasu (35 m) Adapazarı province $\left(41^{\circ} 05 \mathrm{~N} ; 30^{\circ} 42^{\prime} \mathrm{E}\right)$.

In total, 33 Rana dalmatina (6 males, 25 females and 2 semi-adults) were examined for helminth parasites. The mean \pm SD snout-vent length (SVL) of specimens was $50.05 \pm 10.45 \mathrm{~mm}$, with a range from 27 to $66 \mathrm{~mm}$.

Frogs were overdosed in ether-filled glass containers, fixed by injecting $7 \%$ formalin into the body cavity and preserved in $70 \%$ ethyl alcohol. The body cavity was opened by a longitidutinal ventral incision. The alimentary canal was excised and separated into stomach, small intestine, large intestine and rectum. The contents of each part and other organs (lungs, liver, gall bladder, kidneys and urinary bladder) were each mixed with $0.5 \%$ saline solution and poured into Petri dishes for examination under a stereomicroscope. The muscles, plus portions of peritoneum and spinal cord, were teased out with needles and examined under a stereomicroscope. Trematodes were stored in $70 \%$ ethanol. Nematodes were stored in $70 \%$ ethyl alcohol with $5 \%$ glycerol, and Acanthocephalans were stored in $70 \%$ ethyl alcohol. Digeneans and acanthocephalans were stained with acetocarmine, dehydrated, cleared in cedar oil or xylol, and mounted in Canada Balsam; nematodes were 


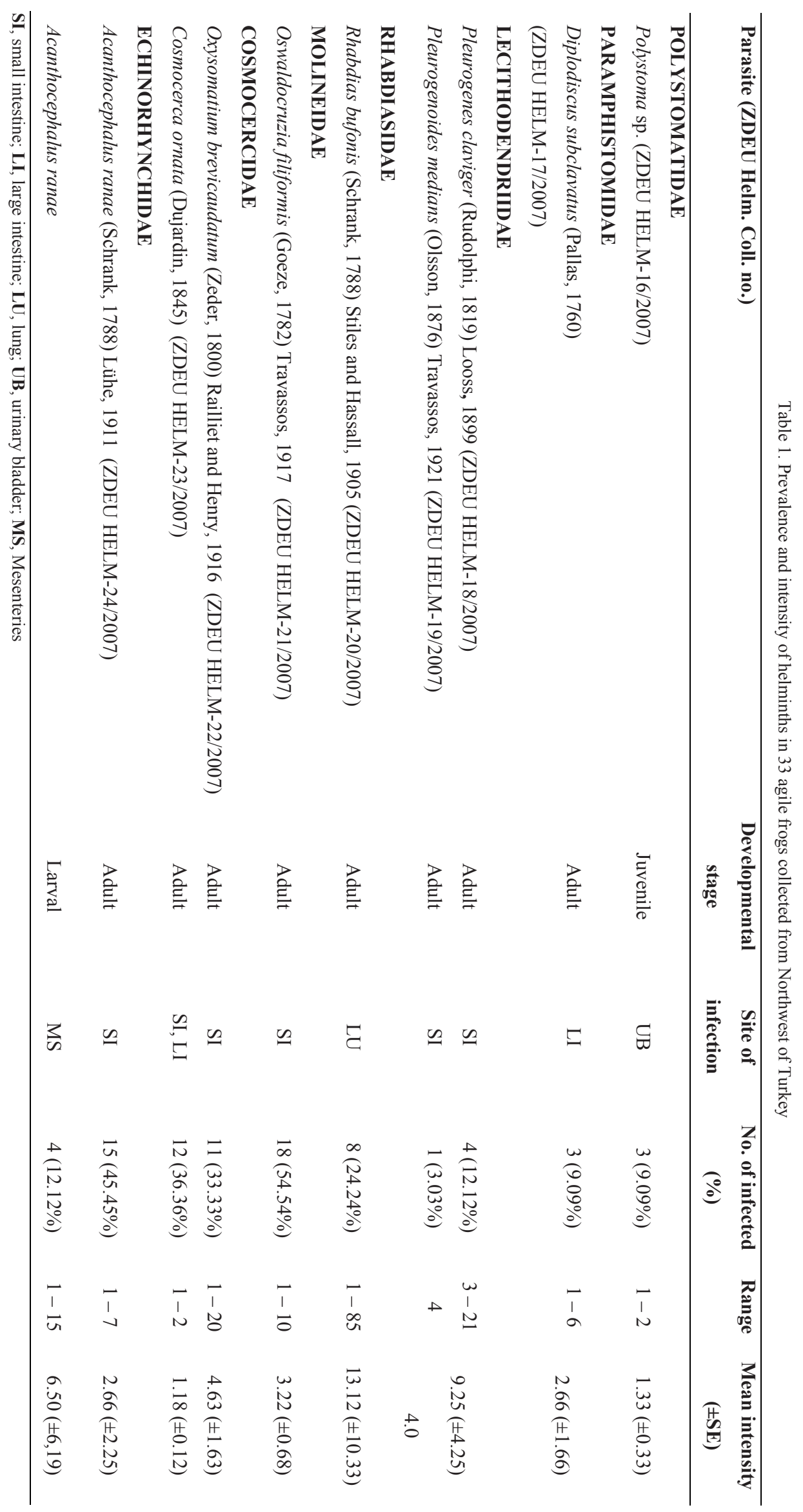




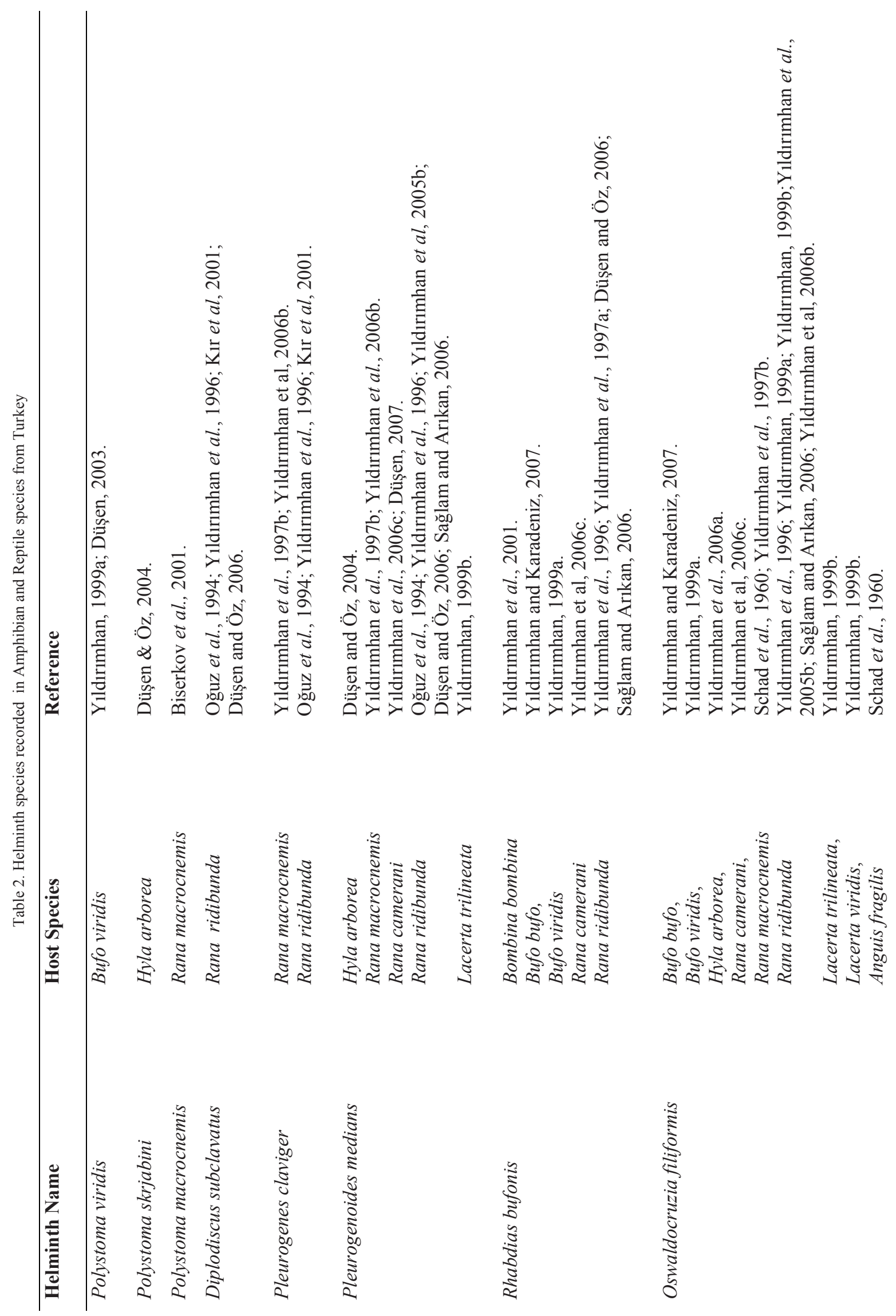




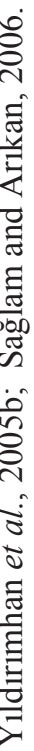

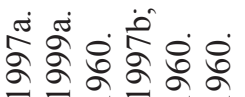

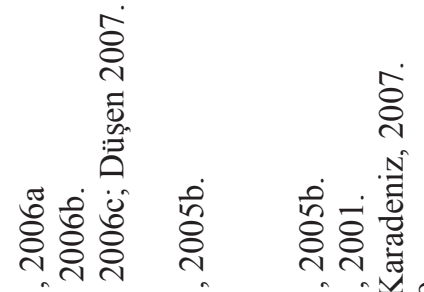

官高

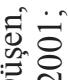

๘ิ

8 ๘

芒艺完

एँ

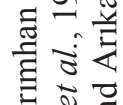

हี่

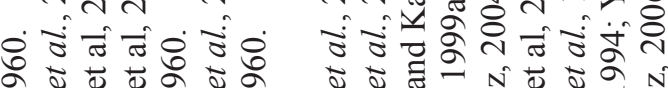

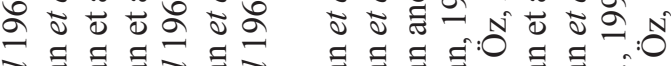

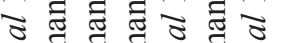

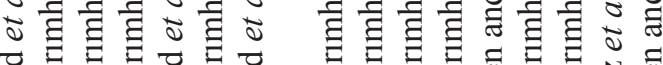

छ히 छั

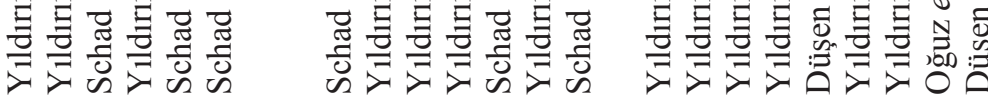
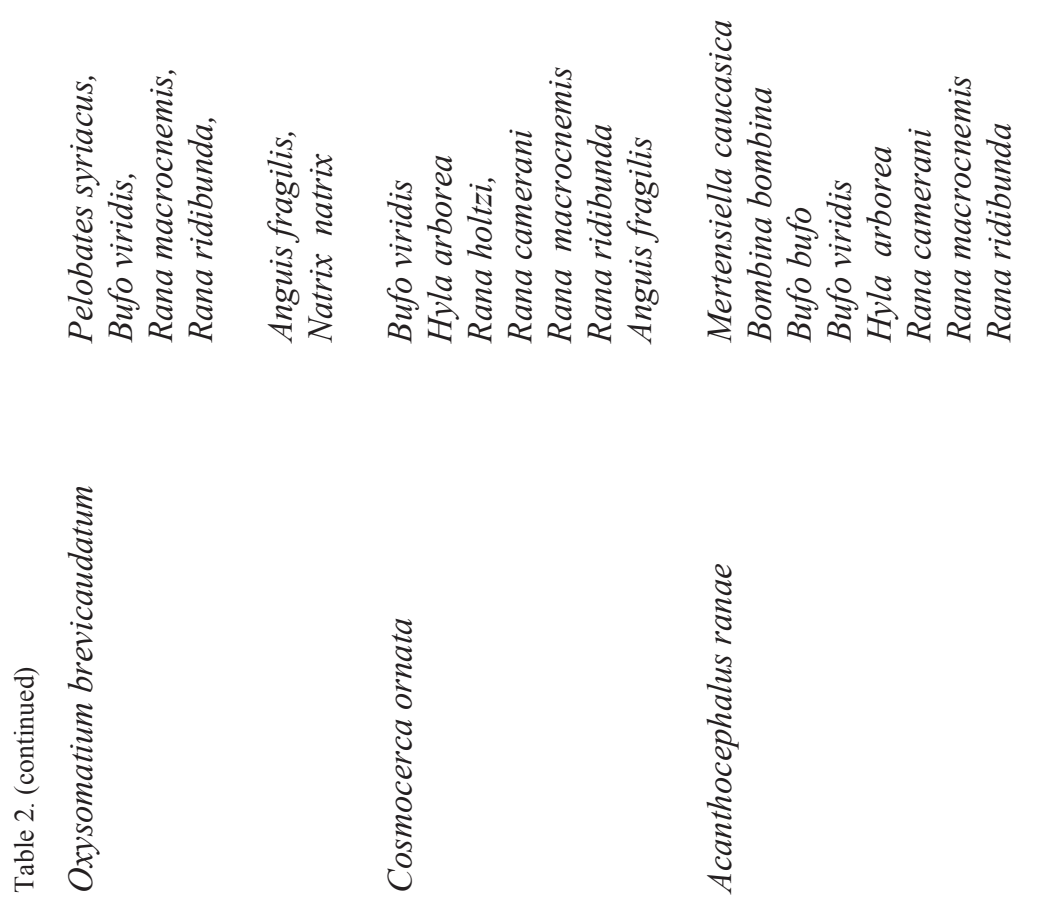

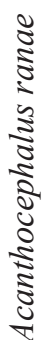


cleared in glycerol and examined. Intensities are presented as mean values ( $\pm 1 \mathrm{SE}$ ) followed by the range.

Voucher specimens of parasites were deposited in the Ege University, Museum of Zoology, Izmir, Turkey (ZDEU HELM-16-24/2007); host specimens were deposited in the Uludağ University, Faculty of Arts and Sciences Department of Biology, Bursa Turkey.

\section{Results and Discussion}

In summary, 344 individuals of 9 helminth species were collected from 33 anurans examined. Helminths were collected from the large and small intestine, urinary bladder, lungs and body cavity mesenteries (Table 1 ).

No individual host harbored more than 6 helminth species. Of the infected anurans, $1(3.03 \%)$ harbored 6 species of helminth, $1(3.03 \%)$ harbored 5 species of helminth, $2(6.06 \%)$ harbored 4 species of helminth; $13(39.39 \%)$, harbored 3 species of helminth; 8 (24.24\%), harbored 2 species of helminth; and $8(24.24 \%)$, harbored 1 species of helminth.

There were $2.48 \pm 1.20$ helminth species per infected host and $10.60 \pm 3.4$ helminth individuals per infected host. Of the 9 helminth species found in this study, 6 helminths had prevalences greater than $10 \%, A$. ranae was the most prevalent helminth, occurring in 19 of 33 hosts $(57.6 \%)$, followed by $O$. filiformis with 18 of 33 hosts (54.54\%), C. ornata with 12 of 33 hosts (36.36\%), O. brevicaudatum with 11 of 33 hosts $(33.33 \%), R$. bufonis with 8 of 33 hosts (24.24\%) and $P$. claviger with 4 of 33 hosts (12.12\%).

This is the first published study of helminths of $R$. dalmatina from Turkey. All helminths collected are new host records for Rana dalmatina in Turkey. Buchvarov et al. (1975) reported 3 species of nematodes (Cosmocerca ornata, C. commutata, Oswaldocruzia filiformis) in Velingrad district (Bulgaria); Vojtkova and Vojtek (1975) reported 6 species of trematodes (Diplodiscus subclavatus, Opistioglyphe ranae, Haplometra cylindracea, Euryhelmis squamula, and metacercarian stages of Enyclometra colubrimurorum, O. ranae and Echinoparyphium recurvatum) in the $R$. dalmatina from the former Czechoslavakia. Buchvarov (1977) recorded 8 species of trematodes (Diplodiscus subclavatus, Opistioglyphe ranae, Pneumonoeces variegatus, Cephalogonimus retusus, Gorgodera pagenstecheri, Gorgoderina vitelliloba, Pleurogenoides medians, and Tylodelphis rhachiaea), 6 species of nematodes (Cosmocerca ornata, C. commutata, Oswaldocruzia filiformis, O. bialata, O. brevicaudatum, and Rhabdias bufonis), one species of acanthocephalan (Acanthocephalus ranae) and one species of leech (Batracobdella algira) in R. dalmatina collected from Bulgaria. Also, Kirin and Buchvarov (2002) observed one species of nematote ( $O$. filiformis) from Britsa riverside in Bulgaria. Similiarly, we observed $D$. subclavatus, P. medians, $R$. bufonis, C. ornata, Oswaldocruzia filiformis, $O$. brevicaudatum, and A. ranae in this study in $R$. dalmatina in Turkey. No leech species were found in this investigation.

$R$. dalmatina represents a new host record for Polystoma sp. There are 3 species of Polystoma that have been reported from Turkey: Polystoma macrocnemis in the Uludağ frog (Rana macrocnemis), Polystoma skrjabini in the European tree frog (Hyla arborea), and Polystoma viridis in the European green toad, (Bufo viridis) (Yıldırımhan, 1999a; Biserkov et al., 2001; Düşen \& Öz, 2004). Buchvarov (1980) reported a new species, Polystoma mazurmovici in $R$. dalmatina from Bulgaria. We were unable to identify the species of Polystoma collected in this study, because the specimens are juvenile forms.

The other helminth species (D. subclavatus, Pleurogenes claviger, P. medians, R. bufonis, Oswaldocruzia filiformis, $O$. brevicaudatum, C. ornata and A. ranae) found in this study are common parasites of European anurans (see Yamaguthi, 1963; Buchvarov, 1977; Prudhoe \& Bray, 1982; Anderson, 2000) and these species have been observed in several amphibians and some reptiles species in Turkey (Table 2).

This study has expanded the geographical and host range distribution of various helminth species. Future studies should also expand the host-parasite list from Turkey.

This information may then be used to increase our understanding of parasite-host relationships.

\section{Acknowledgments}

We thank to the Department of National Parks and Wildlife of the Ministry of Forestry, of the Republic of Turkey for their helps and permission.

\section{References}

ANDERSON R. C. (2000): Nematode Parasites of Vertebrates: Their Development and Transmission (2nd Edition). CABI Publishing, Wallingford, Oxon, U.K.

BARAN, I., ATATÜR, M. K. (1997): Turkish Herpetofauna. The Republic of Turkey, Ministry of Environment Publications, Ankara.

Biserkov, V. Y., Yildirimhan, H. S., Buchvarov, G., Ugurtas, I. H. (2001): Polystoma macrocnemis n. sp. (Monogenea: Polystomatidae) from the Iranian longlegged wood frog Rana macrocnemis (Ranidae) in Turkey. Syst. Parasitol., 48: 61 - 66

Buchvarov, G. K. (1977): Catalogue des Helminthes des Amphibies en Bulgarie, Universite de Plovdiv "P Hilendarski," Plovdiv, Bulgaria. (In Bulgarian)

Buchvarov, G. K. (1980): Polystoma mazurmovici n.sp. (Polystomatidae Gambl, 1896), a parasite of Rana dalmatina Bonaparte, 1839 in Bulgaria. Nauchni Trudove, Plovdivski Universitet "Paisii Khilendarski", Bulgaria. (In Bulgarian)

Buchvarov, G. K., Petrov, P., Chochev, B. (1975): To the Question about Helminthofauna of Amphibious Eucaudate (Amphibia-Eucaudata) of Velingrad's District. Universite de Plovdiv "P Hilendarski", Travaux Scientifiques, Biologie, 13 (4): 53 - 64 (In Bulgarian, with English Abstract) 
DÜŞEN, S. (2003): The Helminth Fauna of Tailless Frog Species (Ordo: Anura) Distributed in Antalya. Akdeniz University, Antalya, Turkey. 116 pp. PhD thesis (in Turkish with English Abstract)

DüşEN, S. (2007): Helminths of the two mountain frogs, Banded frog, Rana camerani Boulenger, 1886 and Uludağ Frog Rana macrocnemis Boulenger, 1885 (Anura: Ranidae), collected from Antalya Province. Acta Parasitol. Tur., 31 (1): $84-88$

DüşEN S., Öz, M. (2004): Helminth parasites of the tree frog, Hyla arborea (Linnaeus, 1758) (Anura: Hylidae) from Southwest Turkey. Comp. Parasitol., 71 (2): 258 261

DÜŞEN S., Öz, M. (2006): Parasitic helminths of the marsh frog, Rana ridibunda Pallas, 1771 (Anura: Ranidae), from Antalya Province, south-west Turkey. Comp Parasitol., 73 (1): $121-129$

KIR, İ., YIldirim, M. Z., BeCER, A., İKIZ, R. (2001): Feeding habits and parasites of the lake frogs (Rana ridibunda Pallas 1771; Anura: Ranidae) of Lake Eğirdir. Acta Parasitol. Tur., 25 (1): 83 - 87 (in Turkish, with English Abstract)

KIRIN, D., BuChVAROV, G. (2002): Biodiversity of of the helminth communities of acaudated Amphibians (Amphibia: Ecaudata) from Bistritsa Riverside (Gotse Delchev Region). Exp. Pathol. and Parasitol., 5 (8): 13 16

OĞUZ, M. C., Altunel, F. N., UĞURtaş, İ. H. (1994): An investigation of the species of Platyhelminthes and Acanthocephalus ranae (Schrank, 1788, (Echinorchynchidae, Acanthocephala) of marsh frogs (Rana ridibunda Pallas, 1771) which were collected from the Bursa and Edirne Regions. Tr. J. of Zool., 18: 47 - 51 (in Turkish, with English Abstract).

Prudhoe, S., A. BRAY, S. (1982): Platyhelminth Parasites of Amphibia. British Museum of Natural History. Oxford University Press, London.

SAĞLAM, N., ARIKAN, H. (2006): Endohelminth parasites of the Marsh Frog Rana ridibunda from Hazar Lake, Turkey. Dis. Aquat. Org., 73: $253-260$

Schad, G. A., Kuntz, R. E., Wells, W. H. (1960): Nematode parasites from Turkish vertebrates: an annotated list. Can. J. Zool., 38: $949-963$

VojtKovÁ, L., Vojtek, J. (1975): Die Trematoden der Amphibian inder Tschechowakei (Motolice Obojživelniků CSSR) II Larval stadian (Mesocercariana und metacercarien) Folia Biologia, Czechoslovakia.

YAMAGUTI, S. (1963): Systema Helminthum. Acanthocephala. Vol.V. Intersciences Publishers, London, England.

YILDIRIMHAN, H. S. (1999a): Researches on parasitic helminths of Bufo viridis Laurenti, 1768 (Anura: Amphibia).
Tr. J. of Zool, 23: 177 - 195 (in Turkish with English abstract)

YILDIRIMHAN, H. S. (1999b): The helmint fauna of lizard species Lacertidae (Reptilia) Distributed in Bursa region. Uludağ University. Bursa Turkey. 120 pp, Bursa. (Unpublished $\mathrm{PhD}$ thesis) (in Turkish with English Abstract)

Yildirimhan, H. S., Altunel, F. C., UĞurtaș. İ. H. (2006a): Helminth Parasites of Hyla arborea (Linneaus, 1758) (Tree Frog) collected from Bursa, Edirne and Sakarya. Acta Parasitol. Tur, 30 (1): 56 - 59 (In Turkish, with English Abstract)

Yildirimhan, H. S., AYdoĞdu, A., UĞURTAŞ, I. H., Altunel, F. N. (2001): Helminth fauna of Bombina bombina (Linnaeus, 1767) Fire-bellied toad from Sakarya and Edirne (Turkey). Acta Parasitol. Tur., 25 (3): 308 311 (in Turkish, with English Abstract)

Yildirimhan, H. S., Bursey C. R., GoldberG, S. R. (2005a): Helminth parasites of the Caucasian salamander, Mertensiella caucasica, from Turkey. Comp. Parasitol., 72 (1): $75-87$

Yildirimhan, H. S., Bursey, C. R. GoldberG S. R. (2006b): Helminth parasites of the Taurus frog, Rana holtzi, and the Uludag frog, Rana macrocnemis, with remarks on the helminth community of Turkish anurans. Comp. Parasitol., 73 (2): $237-248$

Yildirimhan, H. S., GoldBerG, S. R. Bursey, C. R. (2006c): Helminth parasites of the Banded Frog, Rana camerani (Ranidae) from Turkey. Comp. Parasitol., 73 (2): $222-236$

Yildirimhan, H. S., Karadeniz, E. (2007): Helminth Parasites of the Common Toad, Bufo bufo (Linnaeus, 1758) (Anura: Bufonidae) from Northeast Turkey. Comp. Parasitol., (1): 176 - 178

Yildirimhan, H. S., KARAdENIZ, E., GÜRKAN, E., KoYUn, M. (2005b): Metazoon parasites of the Marsh frog (Rana ridibunda Pallas, 1771; Anura) collected from the different regions in Turkey. Acta Parasitol. Tur., 29 (2): 135 - 139 (in Turkish, with English Abstract)

Yildirimhan, H. S., OĞUZ, M. C., UĞURTAŞ, İ. H. (1997a): An investigation on the nematodes some of Tailles frogs (Rana ridibunda, Bufo bufo, Pelobates syriacus) collected from the Bursa Region.. Hacettepe Fen ve Müh. Bil. Derg., 18: 45 - 58 (in Turkish, with English Abstract)

Yildirimhan, H. S., UĞURTaş, İ. H., Altunel, F. N. (1996): An investigation Helminths of Rana ridibunda Pallas, 1771 (Marsh Frogs). Acta Parasitol. Tur., 20: 113 130 (in Turkish, with English Abstract)

Yildirimhan, H. S., UĞURTaş, İ. H. Altunel, F. N. (1997b): An investigation on parasitic helminths of Rana macrocnemis Boulenger, 1885 (Uludag frog). Tr. J. of Zool., 21: $467-473$ 